\title{
An Ethnobotanical Study of Medicinal Plants With Antianxiety and Antidepressant Effects in Shahrekord
}

\author{
H. Teimouri' ${ }^{1}$, S. Abbaszadeh ${ }^{2,3,4}$, B. Farzan*5 \\ ${ }^{1}$ Associated Professor, Department of Anesthesiology, Lorestan University of Medical \\ Sciences, Khorramabad, Iran. \\ ${ }^{2}$ Razi Herbal Medicines Research Center, Lorestan University of Medical Sciences, \\ Khorramabad, Iran. \\ ${ }^{3}$ Student Research Committee, Lorestan University of Medical Sciences, Khorramabad, \\ Iran. \\ ${ }^{4}$ Hepatitis Research Center, Lorestan University of Medical Sciences, Khorramabad, \\ Iran \\ ${ }^{5} \mathrm{MD}$, Associated Professor, Department of Anesthesiology, Lorestan University of \\ Medical Sciences, Khorramabad, Iran.
}

\begin{abstract}
NXIETY and depression are two highly prevalent disorders in all human communities. $A$ The purpose of the present study was to report medicinal plant species that local people, according to their ethnobotanical knowledge, in Shahrekord use as antianxiety and antidepressant agents. The present ethnobotanical study was carried out to report and collect indigenous knowledge in the studied region in 2017 via face-to-face interviews and by using a questionnaire distributed among 29 traditional therapists. To this end, interviewers referred to respondents in person to elicit their pharmacological and ethnobotanical knowledge, and then register their viewpoints related to herbal medicine. The data extracted from the questionnaires were appropriately and meticulously tabulated, and data analysis was done by the Excel software. In this study, the formula below was used to calculate the frequency of plant use. Medicinal plants that are used as antianxiety and antidepressant drugs according to the ethnobotanical knowledge in Shahrekord include Fritillaria imperialis L., Ducrosia anethifolia L., Anchusa italyca Retz. (L.) DC., Dracocephalum multicaule, Stachys lavandulifolia, Thymus vulgaris, Tripleurospermum parviflorum L., Crataegus persica, Hypericum scabrum L., Valeriana officinalis, Centaurea cyanus, Rheum ribes L. and Melissa officinalis L are the most herbal plants effective on anxiety and depression on shahrekord ethno-botany.
\end{abstract}

Keywords, Neurological disorders, Anxiety, Depression, Ethnobotany, Medicinal plants.

\section{Introduction}

Psychiatric disorders are currently widespread across the globe. Anxiety and depression are two highly prevalent disorders in all human societies [1-3]. By definition, anxiety is a kind of natural feeling that is experienced in threatening situations. Clinical features of anxiety disorders are similar to and do not differ in type from those of normal anxiety, but differ in duration and severity. Anxiety disorders are one of the major humans' issues [4]. Reduced synaptic threshold during anxiety increases the defensive response to normal stimuli. Studies have demonstrated the wide role of neurochemical systems in anxiety $[5,6]$. Anxiety is a type of mental uneasiness, perturbation and concern accompanied by physiological changes such as increased heart rate, hypertension, increased respiratory rate, and increased muscle tone, leading to the patient's

*Corresponding author, Behrouz Farzan, e-mail.b farazan41@yahoo.com, Tel.00989119182429

DOI. 10.21608/ejvs.2019.12612.1077

C2019 National Information and Documentation Center (NIDOC) 
preparation for escape or defense [7-9]. Anxiety and depression are two of the major health issues in human communities, so that more than $20 \%$ of the US population suffer from the two disorders. Typically, chemical drugs used for anxiety disorders cause certain side effects, including dependency, drug withdrawal syndrome if the drug discontinued, sleepiness and lethargy [10]. Depression can dramatically decrease the performance of the patient in all areas including occupation and social and family relationships, and also leads to the lack of pleasure and emotional and mental pressures. Patients with depression may reach such a state of hopelessness that thoughts of suicide occur in them [11]. Depression in today's society is considered a serious illness. This disease is one of the most common chronic diseases so that one out of ten outpatients suffers from major depressive disorder [12]. Depression is a common disease and most of patients with depression need treatment to improve. Although many compounds are used to treat depression, most of them lead to several unwanted reactions, including anticholinergic effects, orthostatic hypotension, and arrhythmias. Therefore, effective drugs with less toxicity are needed [13]. Accordingly, research attempts are being made to seek out effective drugs with less side effects. One of the options available to achieve this purpose, is medicinal plants that are used in the treatment of various diseases. The use of medicinal plants for the treatment of various diseases dates back to centuries ago [14]. Today, although a large proportion of the drugs used are chemical, it is estimated that at least one third of all medicinal products are plant-based, or are transformed after isolation from the plant. This drug source is used in the treatment of various diseases [15-26]. People have constantly been thinking of using medicinal plants to heal their illnesses and relieve their pain. These drugs have been used since old times and are the basis of the ethnobotany science. Ethnobotany deals with the use of medicinal plants in traditional medicine in different cultures. The purpose of the present study was to report medicinal plant species that local people use in Shahrekord as antianxiety and antidepressant agents.

Egypt. J. Vet. Sci. Vol. 50, No.1 (2019)

\section{Materials and Methods}

Studied region and data collection protocol The present ethnobotanical study was carried out to report and obtain indigenous information and knowledge about antianxiety and antidepressant effects of medicinal plants in Shahrekord in 2017 via face-to-face interviews and a questionnaire distributed among 29 traditional therapists. The questionnaire that had previously been prepared was administered to the traditional therapists by the interviewers. The questionnaire included information about the location and demographic characteristics of the respondent, the local name of the plant and its organ(s) used. The interviewers referred to respondents in person to elicit their pharmacological and ethnobotanical knowledge, and then record their viewpoints related to herbal medicine. Out of 29 people, eight were female and 21 male. Their education level was from high school diploma to master's degree. The data of the questionnaires were meticulously and appropriately tabulated, and were finally analyzed by the Excel software. In this study, the frequency of plant use was calculated per the formula below,

The frequency of use of the plant $=$ (Number of people reporting the plant's effect divided by total number of people filling out the questionnaires) $\times 100$

\section{Results}

Results showed that 13 species of medicinal plants in Shahrekord are used as antianxiety/ antidepressant agents (Table 1, Fig. 1 \& 2).

Figure 1 shows the distribution of plant families. As illustrated in Figure 1, the Lamiaceae family has the highest number of medicinal plants with antianxiety and antidepressant effects. The distribution of the number of other plant families is indicated in Fig. 1.

Figure 2 also illustrates the percentage of the frequency use of plants organs. Accordingly, the most frequently used plant organ for treatment of anxiety and depression was flower (33\%) followed by leaf ( $29 \%)$. Additional information on the use of other plant organs is illustrated in Fig. 2. 
TABLE 1. Ethnobotanical information about medicinal plants with antianxiety and antidepressant property in the Shahrekord region.

\begin{tabular}{|c|c|c|c|c|c|}
\hline Scientific name & Herbal name & Local name & $\begin{array}{l}\text { Frequency } \\
\text { of use }\end{array}$ & $\begin{array}{c}\text { Organs } \\
\text { used }\end{array}$ & Effect \\
\hline Fritillaria imperialis $L$. & Liliaceae & Laleh vajgoun & $24 \%$ & Bulb & $\begin{array}{l}\text { Anti-anxiety/ } \\
\text { depression }\end{array}$ \\
\hline Ducrosia anethifolia L. & Apiaceae & Moshkak & $31 \%$ & $\begin{array}{l}\text { Aerial } \\
\text { organs }\end{array}$ & $\begin{array}{l}\text { Anti-anxiety/ } \\
\text { depression }\end{array}$ \\
\hline $\begin{array}{c}\text { Anchusa italyca Retz. } \\
\text { (L.) DC. }\end{array}$ & Boraginaceae & Gavzaban & $34 \%$ & $\begin{array}{l}\text { Folwer, } \\
\text { root, leaf }\end{array}$ & $\begin{array}{c}\text { Anti-anxiety/ } \\
\text { depression }\end{array}$ \\
\hline $\begin{array}{c}\text { Dracocephalum } \\
\text { multicaule Montbr \& } \\
\text { Auch. }\end{array}$ & Lamiaceae & Zarrin giah & $44 \%$ & Leaf & $\begin{array}{l}\text { Anti-anxiety/ } \\
\text { depression }\end{array}$ \\
\hline Stachys lavandulifolia & Lamiaceae & Chaye kouhi & $3 \%$ & Leaf, stem & $\begin{array}{l}\text { Anti-anxiety/ } \\
\text { depression }\end{array}$ \\
\hline Thymus vulgaris & Lamiaceae & Avishan & $24 \%$ & Leaf & $\begin{array}{c}\text { Anti-anxiety/ } \\
\text { depression }\end{array}$ \\
\hline $\begin{array}{l}\text { Tripleurospermum } \\
\text { parviflorum L. }\end{array}$ & Asteraceae & $\begin{array}{l}\text { Babouneh } \\
\text { kazeb }\end{array}$ & $1 \%$ & Flower & $\begin{array}{l}\text { Anti-anxiety/ } \\
\text { depression }\end{array}$ \\
\hline Crataegus persica & Rosaceae & Zalzalak & $6 \%$ & Leaf, fruit & $\begin{array}{l}\text { Anti-anxiety/ } \\
\text { depression }\end{array}$ \\
\hline Hypericum scabrum L. & Hypericaceae & Gole raei & $6 \%$ & Flower & $\begin{array}{l}\text { Anti-anxiety/ } \\
\text { depression }\end{array}$ \\
\hline Valeriana officinalis & Caprifoliaceae & Sonboilatieb & $6 \%$ & Root & $\begin{array}{l}\text { Anti-anxiety/ } \\
\text { depression }\end{array}$ \\
\hline Centaurea cyanus & Asteraceae & Gole gandom & $3 \%$ & Flower & $\begin{array}{l}\text { Anti-anxiety/ } \\
\text { depression }\end{array}$ \\
\hline Rheum ribes $L$. & Polygonaceae & Rivas & $6 \%$ & $\begin{array}{c}\text { Leaf, } \\
\text { flower, stem }\end{array}$ & $\begin{array}{l}\text { Anti-anxiety/ } \\
\text { depression }\end{array}$ \\
\hline Melissa officinalis $L$ & Lamiaceae & Badranjboyeh & $3 \%$ & $\begin{array}{l}\text { Aerial } \\
\text { organs }\end{array}$ & $\begin{array}{c}\text { Anti-anxiety/ } \\
\text { depression }\end{array}$ \\
\hline
\end{tabular}

\section{Herbal family}

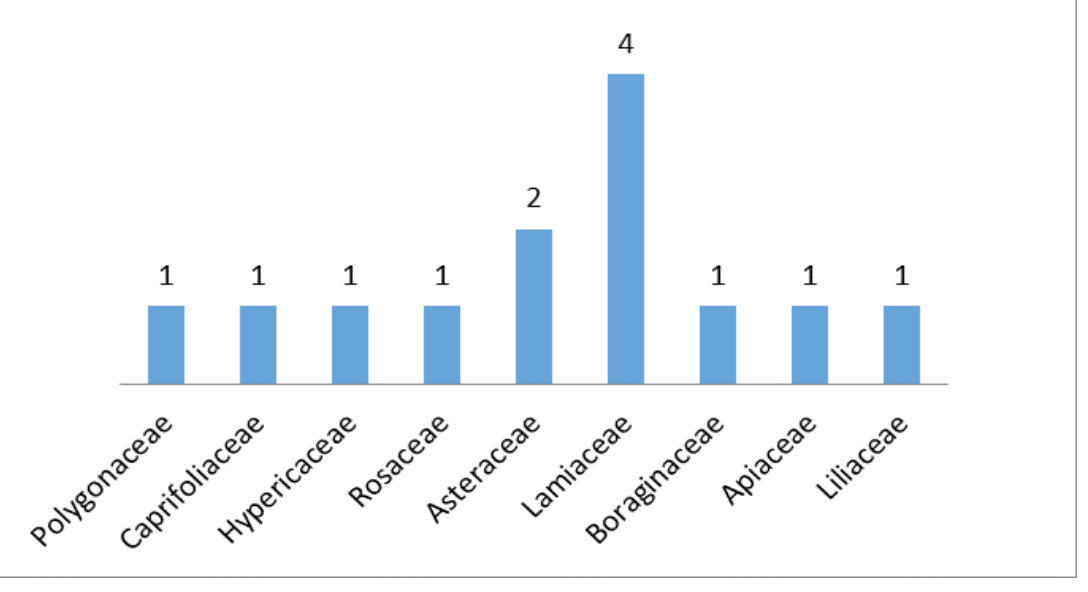

Fig. 1. The distribution of plant families. 


\section{Percentage of used plant organs}

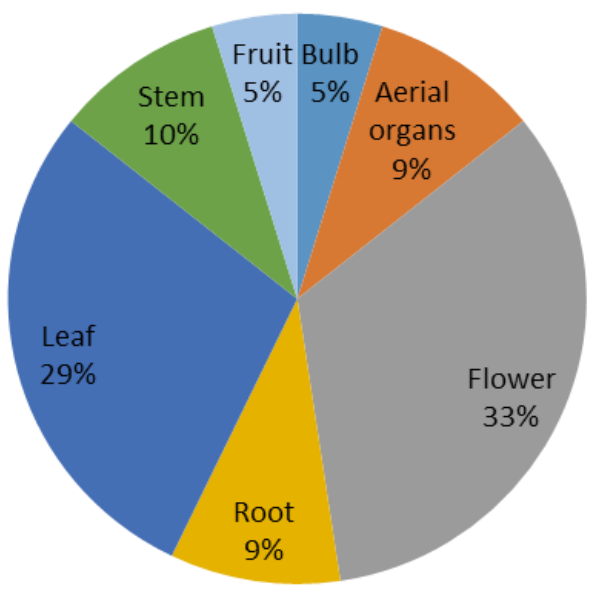

Fig. 2. The percentage of the frequency use of plants organs.

\section{Discussion}

In the process of modulating anxiety, several receptors such as GABA, serotonin, catecholamines and sex hormones are involved [27]. GABA is the most important inhibitory neurotransmitter in the brain. The binding of the GABA to the receptor opens the chloride ion channel and causes the inhibition and hyperpolarization of neurons [28]. Glutamate is also the most important excitatory neurotransmitter in the central nervous system and its effects are exerted through receptors in the membrane called ionotropic receptors and metabotropic receptors. The glutamate concentration is far more in the nervous system than in other tissues of the body, and in synaptic transmission, longterm changes are involved in the irritability of neurons and neuronal development. In spite of the many impacts of glutamate in the physiological function of the neurons, this compound is also a potent neurotoxin, and is involved in many disorders of the central nervous system, including neurodegenerative disorders, ischemia, and trauma [29]. Antidepressants increase the concentration of one or more of the chemical substances of the brain, namely, neurotransmitters that the brain nerves use to establish communication with each other. Neurotransmitters that are affected by antidepressants include norepinephrine, serotonin and dopamine. In depression, serotonin and noradrenaline are impaired [30,31]. Medicinal plants reported in this study are likely to produce Egypt. J. Vet. Sci. Vol. 50, No.1 (2019) antianxiety and antidepressant effects through a mechanism similar to that of chemical drugs. Antianxiety and antidepressant properties of some of these plants or other ones have been confirmed in experimental and clinical trials [3236]. However, the mechanisms involved in their actions are not clear.

It has been shown that there is an association between oxidative stress and neuropsychiatric disorders including anxiety and depression. In fact, development of anxiety or depression is associated with a decrease in antioxidant status and increase in oxidative stress. Depression therapy, even with conventional drugs is also associated with increase in antioxidant levels and reduction in damages induced by oxidative stress [37].

Antioxidants scavenge free radicals such as reactive oxygen species (ROS) and reactive nitrogen species (RNS) and reduce oxidative stress preventing neuronal damage caused. This may result in reduction of anxiety and depression symptoms. The relation between oxidative stress and anxiety or depression opens a novel target for treatment of neurodegenerative and neuropsychiatric disorders [37]. The plants mostly, including the presented plants in this article have antioxidant activities. In this regard a lot of medicinal plants with antioxidant activity have been shown to be effective against anxiety and depression [38-47]. Furthermore, these patients mostly have other disease and plants usually are 
effective against a number of diseases [48-51]. Therefore, these plants might be beneficial for them more than conventional drugs. These plants or their components due to having antioxidant activity may also be useful if they can be used as complementary with traditional drugs to reduce their toxic effects [51].

\section{Authors' Contributions}

S.A, H.T. and B.F. designed and planned this studyAll authors shared samples collection, performing the tests, manuscript writing, drafted, revised the manuscript and approved the final manuscript.

\section{Acknowledgement}

The authors are thankful from Shahrekord and Lorestan University of Medical Sciences.

\section{References}

1. Valizadeh, R., Veisani, Y., Delpisheh, A., Kikhavani, S., Sohrabnejad, A. Major depression and psychiatric disorders in Iranian prisoners based on a clinical interview, A systematic review and meta-analysis. Shiraz E Med J, 18 (6),e44979 (2017).

2. Mohammadalizadeh Charandabi S, Rezaei,N, Hakimi S, Khatami SH, valizadeh R, Azadi A. Sleep disturbances and sexual function among men aged 45-75 years in an urban area of Iran. Sleep Science, 9 (1), 29-34 (2016).

3. Valizadeh R, Sarokhani D, Sarokhani M, Sayehmiri K, Ostovar R, Angh P, Malekzadeh M. A study of prevalence of anxiety in Iran, Systematic review and meta-analysis. Der Pharma Chemica, 8 (21), 48-57 (2016).

4. KE. WHSAM. Antioxidant activity in extracts from coriander. Food Chermistry 2004, 88 (2), 293-7.

5. Necchi RMM, Ercolani C, Dalmora SL, Manfron MP. Anti inflammatory activity and concentrations of polyphenols and flavonoids in the ethanolic extract of dodonaea viscosa (Sapindaceae). Saúde (SantaMaria). 38 (1), 113-20 (2012).

6. Getie M, Gebre Marian T, Reitz R, Hohne C, Huschka C, Schmidtke M, Abate A, Neubert, RHH. Evaluation of the antimicrobial and antiinflammatory activities of the medicinal plants Dodonaea viscosa, Rumex nervosus and Rumex abyssinicus. Fitoterapia, 74, 139-143 (2003).

7. Linden C. Anxiety and Panic Attacks Solution, Reprogramming your anxiety with the Linden Method Available from, http,//www.Lindenmethod. com.
8. Clement Y, Chapouthier G. Biological bases of anxiety. Neurosci Biobehav Rev. Sep, 22 (5),623633 (1998).

9. Clément Y, Calatayud F, Belzung C. Genetic basis of anxietylike behaviour, a critical review. Brain Res Bull. 57 (1),57-71(2002).

10. Niksokhan M, Hedarieh N, Najafifard Maryam, Najafifard Masoomeh. [Effect of hydro-alcholic extract of Pimpinella anisum seed on anxiety in male rat]. J Gorgan Uni Med Sci., 16(4), 2833(2015).

11. Kaplan HI, Sadocks BJ. Synopsis of psychiatry behavioral sciences, clinical psychiatry. Translated to Persian by, Rafiee H, Rezaee F. 10th ed. Tehran, Arjmand Pub, 2008. p, 80, 38-87.

12. Whooley MA, Simon GE. Managing depression in medical outpatients. N Engl J Med., 26(343), 19421950 (2000).

13. Koenig AM, Thase ME. Firstline pharmacotherapies for depression - what is the best choice? Pol Arch Med Wewn. 119 (7-8), 478-86 (2009).

14. Jamshidi-Kia F, Lorigooini Z, Amini-Khoei H. Medicinal plants, past history and future perspective. Journal of Herbmed Pharmacology.,1,1-7 (2018).

15. Ghanadi K, Hasanvand A, Abbaszadeh S, HeidariSoureshjani S, Suhan T. Phytotherapy, An antihepatotoxicity and hepatoprotective approach in chemotherapy. Plant Science Today., 6 (2),114-122 (2019).

16. Froushani SMA, Zarei L, Ghaleh HEG, Motlagh BM. Estragole and methyl-eugenolfree extract of Artemisia dracunculus possesses immunomodulatory effects. Avicenna Journal of Phytomedicine, 6 (5), 526-534 (2016).

17. Abbasi N, Azizi Jalilian F, Abdi M, Saifmanesh M. A comparative study of the antimicrobial effect of Scrophularia striata Boiss. Extract and selective antibiotics against Staphylococcus aureus and Pesudomonas aeruginosa. Journal of Medicinal Plants, 6 (SUPPL. 1), pp. 10-18+69 (2007).

18. Anbari K, Hasanvand A, Andevari AN, Abbaszadeh S. Concise overview, A review on natural antioxidants and important herbal plants on gastrointestinal System. Research Journal of Pharmacy and Technology.,12(2),841-847(2019). 
19. Kheirollahi A, Hasanvand A, Abbaszadeh S, Moghadasi M. Pathophysiology and Urinary System Cancer, An Overview of the most important Herbal Plants and Natural Antioxidants on Kidney and Bladder Disorders. Research Journal of Pharmacy and Technology.,12(2),972-980 (2019).

20. Bahmani, M., Khaksarian, M., Rafieian-Kopaei, M., Abbasi, N. Overview of the therapeutic effects of Origanum vulgare and hypericum perforatum based on Iran's ethnopharmacological documents. Journal of Clinical and Diagnostic Research, 12 (7), 1-4 (2018).

21. Shokri Z, Khoshbin M, Koohpayeh A, Abbasi N, Bahmani F, Rafieian-Kopaei, M, Beyranvand F. Thyroid diseases, Pathophysiology and new hopes in treatment with medicinal plants and natural antioxidants. International Journal of Green Pharmacy, 12 (3), 473-482 (2018).

22. Abbasi N, Mohammadpour S, Karimi E, Aidy A, Karimi P, Azizi M, Asadollahi K. Protective effects of smyrnium cordifolium boiss essential oil on pentylenetetrazol-induced seizures in mice, Involvement of benzodiazepine and opioid antagonists. Journal of Biological Regulators and Homeostatic Agents, 31 (3),683-689 (2017).

23. Nazer MR, Abbaszadeh S, Anbari KH, Shams M. A review of the most important medicinal herbs affecting giardiasis. Journal of Herbmed Pharmacology, , 8 (2), 78-84 (2019).

24. Tajbakhsh M, Karimi A, Tohidpour A, Abbasi N, Fallah F, Akhavan MM.The antimicrobial potential of a new derivative of cathelicidin from Bungarus fasciatus against methicillin-resistant Staphylococcus aureus. Journal of Microbiology, 56 (2), 128-137 (2018).

25. Bahmani M, Taherikalani M, Khaksarian M, Rafieian-Kopaei M, Ashrafi B, Nazer M et al., The synergistic effect of hydroalcoholic extracts of Origanum vulgare, Hypericum perforatum and their active components carvacrol and hypericin against Staphylococcus aureus. Future Sci OA. 31,5(3),FSO371(2019). doi, 10.4155/fsoa-20180096. eCollection 2019 Mar.

26. Farzan B,Abbaszadeh S, Basati GH, Teimouri H. An overview of the most important medicinal plants effective on the strength of memory and mind in Iranian ethnobotany.|[Una revisión de las plantas medicinales más importantes, eficaces en el fortalecimiento de la memoria y la mente en la etnobotánica iraní]. J. Pharm Pharmacogn Res., 7 (3), 156-162 (2019).
27. Enoch MA. The role of GABAA receptors in the development of alcoholism. Pharmacol Biochem Behav., 90 (1), 95-104 (2008).

28. Kittler JT, Moss SJ. Modulation of GABAA receptor activity by phosphorylation and receptor trafficking, implications for the efficacy of synaptic inhibition. Curr Opin Neurobiol., 13 (3), 341-347 (2003).

29. Shahraki A. Metabotropic glutamate receptors and their ligands applications in neurological and psychiatric disorders. Physiol Pharmacol., 15 (1), 72-89 (2011).

30. Cutler AJ, Montgomery SA, Feifel D, Lazarus A, Astrom M and Brecher M. Extended release quetiapine fumarate monotherapy in major depressive disorder, a placebo- and duloxetinecontrolled study. Journal of Clinical Psychiatry, 70 (4), 526-39 (2009).

31. Higuchi T, Murasaki $M$ and Kamijima $K$. Clinical evaluation of duloxetine in the treatment of major depressive disorder placebo and paroxetine controlled double-blind comparative study. Japanese Journal of Clinical Psychopharmacology, 12, 1613-34 (2009).

32. Rabiei Z, Gholami M and Rafieian-Kopaei M. Antidepressant effects of Mentha pulegium in mice. Bangladesh Journal of Pharmacology., 11 (3),711-715(2016).

33. Ghaderi H, Rafieian M and Nezhad HR. Effect of hydroalcoholic Cinnamomum zeylanicum extract on reserpine-induced depression symptoms in mice. Pharmacophore., 9 (2), 35-44 (2018).

34. Alami-Rostami S and Rafieirad M. The effect of hydro-alcoholic Ferulago angulata extract on locomotor activity and anxiety caused by hypoperfusion ischemia in adult male rats. $J$ Herbmed Pharmacol., 7 (1), $51-55$ (2018). doi, 10.15171/ jhp.2018.09.

35. Pirzad Jahromi G, Imani E, Nasehi M and Shahriari A. Effect of Achillea millefolium aqueous extract on memory deficit and anxiety caused by stroke in ovariectomized rats. J Herbmed Pharmacol., 8(2),153-159 (2019). doi, 10.15171/ jhp.2019.24.

36. Rabiei Z, Naderi S and Rafieian-Kopaei M. Study of antidepressant effects of grape seed oil in male mice using tail suspension and forced swim tests. Bangladesh Journal of Pharmacology.,12 (4),397402 (2017). 
37. Xu Y, Wang C, Klabnik JJ and O’Donnell JM. Novel Therapeutic Targets in Depression and Anxiety, Antioxidants as a Candidate Treatment. Curr Neuropharmacol.,12 (2), 108-119 (2014). doi, 10.2174/1570159X11666131120231448

38. Hosseini Z, Lorigooini Z, Rafieian-Kopaei M, Shirmardi HA, Solati K. A review of botany and pharmacological effect and chemical composition of Echinophora species growing in Iran. Pharmacognosy Research., 9 (4),305-312 (2017).

39. Rahimi-Madiseh M, Lorigoini Z, ZamaniGharaghoshi $\mathrm{H}$ and Rafieian-kopaei M. Berberis vulgaris, specifications and traditional uses. Iranian Journal of Basic Medical Sciences., 20 (5), 569587 (2017).

40. Moradi F, Sewell RDE, Lorigooini $Z$ and Rafieian-Kopaei M. Immunosuppressionlipid Metabolism Interplay and Medicinal Plants in Atherosclerosis, A Review. Current Pharmaceutical Design., 24, 1-5(2018). DOI, 10.2174/ 1381612824666180829105309

41. Sarrafchi A, Bahmani M, Shirzad H and RafieianKopaei M. Oxidative Stress and Parkinson's Disease, New Hopes in Treatment with Herbal Antioxidants. Current Pharmaceutical Design, 22 (2), 238-46 (2016).

42. Bahmani M, Sarrafchi A, Shirzad H, RafieianKopaei M. Autism, Pathophysiology and Promising Herbal Remedies. Current Pharmaceutical Design., 22 (3), 277-85 (2016).

43. Shayganni E, Bahmani M, Asgary S and RafieianKopaei M. Inflammaging and cardiovascular disease, Management by medicinal plants. Phytomedicine., 23 (11),1119-26 (2016).

44. Karimi A, Mohammadi-Kamalabadi M, Rafieian-Kopaei M, Amjad L and Salimzadeh I. Determination of antioxidant activity, phenolic contents and antiviral potential of methanol extract of Euphorbia spinidens Bornm (Euphorbiaceae). Tropical Journal of Pharmaceutical Research., 15 (4),759-64 (2016).
45. Rahimi-Madiseh M, Karimian P, Kafeshani M and Rafieian-Kopaei M. The effects of ethanol extract of Berberis vulgaris fruit on histopathological changes and biochemical markers of the liver damage in diabetic rats. Iranian Journal of Basic Medical Sciences., 20 (5),552-556 (2017).

46. Kazemi S, Shirzad H and Rafieian-Kopaei M. Recent Findings in Molecular Basis of Inflammation and Anti-inflammatory Plants. Current Pharmaceutical Design., 24 (14),1551-62(2018). doi, 10.2174/1381 612824666180403122003.

47. Torki A, Khalaji-Pirbalouty V, Lorigooini Z, Rafieian-Kopaei M, Sadeghimanesh A and Rabiei Z. Anchusa italica extract, phytochemical and neuroprotective evaluation on global cerebral ischemia and reperfusion. Brazilian Journal of Pharmaceutical Sciences., 54 (1) 68-72 (2018). http,//dx.doi.org/10.1590/s217597902018000117251.

48. Rouhi-Boroujeni H, Heidarian E, Rouhi-Boroujeni H, Deris F and Rafieian-Kopaei M. Medicinal Plants with Multiple Effects on Cardiovascular Diseases, A Systematic Review. Current Pharmaceutical Design., 23 (7),999-1015(2017).

49. Tamri P. A mini-review on phytochemistry and pharmacological activities of Scrophularia striata. J Herbmed Pharmacol., 8 (2),85-89(2019). doi, 10.15171/jhp.2019.14.

50. Nazarian-Samani Z, Sewell RDE, Lorigooini Z and Rafieian-Kopaei M. Medicinal plants with multiple effects on diabetes mellitus and its complications, a systematic review. Curr Diab Rep., 18, 72(2018). https,//doi.org/10.1007/s11892-018-1042-0

51. Araghi A, Golshahi H, Baghban F, Abouhosseini Tabari M. Ameliorative action of farnesol on cyclophosphamide induced toxicity in mice. $J$ Herbmed Pharmacol., 7 (1),37-43(2018). doi, 10.15171/jhp.2018.07.

(Received 08/05/2019, accepted 19/06/2019) 